\title{
IS LOW BIRTH WEIGHT AFFECTED BY ANXIETY DURING PREGNANCY? A META ANALYSIS
}

\author{
Amalia Ulfah Suparno'), Uki Retno Budihastuti'2), Bhisma Murti1) \\ 1)Masters Program in Public Health, Universitas Sebelas Maret \\ 2)Department of Obstetrics and Gynecology, Dr. Moewardi Hospital, Surakarta
}

\begin{abstract}
Background: Pregnancy is an emotional time, and anxiety is just one of many feelings that pregnant women experience. Untreated antenatal anxiety exposes the fetus to excess glucocorticoids, which may influence birth outcome. This study aimed to investigate the effect of anxiety during pregnancy on low birth weight and premature birth delivery using meta-analysis.

Subjects and Method: A systematic review and meta analysis was conducted by collecting articles from Google Scholar, PubMed, and Science Direct databases. Keywords used "antenatal anxiety"OR "pregnancy anxiety"OR "anxiety during pregnancy" OR "anxiety disorder" OR anxiety OR pregnancy AND "perinatal outcomes"OR "adverse birth outcome" OR "neonatal outcome" OR "low birth weight"OR "infant, low birth weight" OR "Infant, Low Birth Weight". The inclusion criteria were full text cohort studies, published from 2000 to 2021, used English language, and reported adjusted Odds Ratio. Articles that met the criteria were analyzed by Revman 5.3.

Results: This meta-analysis included 10 observational studies. The study reported that high anxiety during pregnancy increased the risk of premature birth delivery 1.49 times than pregnant women with low anxiety $(\mathrm{aOR}=1.49 ; 95 \% \mathrm{CI}=1.33$ to $1.66 ; \mathrm{p}<0.001)$. Meta-analysis using 7 observational studies reported that high anxiety during pregnancy increased the risk of low birth weigth 1.55 than pregnant women with low anxiety $(\mathrm{aOR}=1.55$; $\mathrm{CI} 95 \% 1.26$ hingga 1.91; $\mathrm{p}<0.001)$.

Conclusion: high anxiety during pregnancy increased the risk of poor birth outcome (prematurity and low birth weight).
\end{abstract}

Keywords: anxiety, low birth weight, premature birth

\section{Correspondence:}

Amalia Ulfah Suparno. Masters Program in Public Health, Universitas Sebelas Maret. Jl. Ir. Sutami 36A, Surakarta 57126, Central Java. Email: amaliaulfahsuparno1@gmail.com. Mobile: 0882005711778 